DE ECONOMIST 156, NO. 4, 2008

\title{
MEASURING THE ECONOMIC EFFECTS OF COMPETITION LAW ENFORCEMENT
}

BY

\author{
HENK DON*,**, RON KEMP**,****, JARIG VAN SINDEREN ${ }^{*, * * *}$
}

\begin{abstract}
Summary
Together with a move from a rules-based legal approach to a more economic approach in competition cases, the economic effects of competition law enforcement have received increasing attention. Measuring these effects is important for external accountability of the Competition Authority, for quality control of its decisions and for evaluating the effectiveness of the competition law. This raises many issues in measurement, including the choice of counterfactual, the choice of effects to be measured, and the proper use of available data. The papers in this Special Issue of De Economist discuss these and related issues, based on a broad range of experience in competition law enforcement.
\end{abstract}

Key words: antitrust, competition law enforcement, deterrence, merger control, welfare effects

JEL Code(s): D61, L40, L50

\section{BACKGROUND}

The origin of modern competition policy goes back to the 19th century in the US. It was a response to the emergence of large companies which tried to restrict effective competition, partly by price fixing agreements in order to prevent price wars. This behaviour was at the expense of consumers. In 1890, the Sherman Act was passed. Initially, enforcement of this antitrust act was not very strict and it did not include merger control. Consequently, companies wishing to coordinate prices decided to merge. In response to this behaviour, the Clayton Act of 1914 included the prohibition of mergers that could substantially reduce competition. After several waves of strict and less strict enforcement, in the 1970s there was more criticism on the relatively interventionist enforcement practices and

\footnotetext{
* Erasmus University Rotterdam, Rotterdam, The Netherlands.

** Corresponding author: Frankenstraat 100, 2582 SP, Den Haag, The Netherlands, Tel: +70-3555918; e-mail: don@few.eur.nl.

*** Netherlands Competition Authority, NMa, The Hague, The Netherlands.

**** Wageningen University, Wageningen, The Netherlands.
} 
more emphasis was put on an efficiency rationale behind vertical coordination and mergers. This introduced more of an economic perspective in the evaluations ${ }^{1}$.

In Europe, Germany in particular has a long history in competition law. Here, the prevailing view was that cartels were an instrument to control the instability created by competition and price wars. In 1923, the Cartel Law was introduced. Under this law, cartels were allowed provided that they were registered and that they would not abuse their market power. In 1957, a more strict competition law was passed which focused on the prevention of price fixing and other anti-competitive behaviour. In 1973 merger control was also introduced.

At EU level, the start of competition law can be traced back to the Treaty of Paris (1951) and more formally to the Treaty of Rome (1957). In the Treaty of Paris, there are rules to prevent trade barriers and discriminatory practices which might distort competition among the six member states. There is a ban on agreements and concerted practices between companies which tend to prevent, restrict or distort effective competition. These underlying ideas can also be seen in the Treaty of Rome and later adjustments. Merger control was not included in the Treaty of Rome but was introduced by the Merger Regulation of 1989. From the start, the primary goal of European regulation was the elimination of any discrimination on the grounds of nationality between the member states. Competition law was a means to promote economic progress and welfare for European citizens.

The Netherlands competition law dates from 1998 and is based on the European competition law. The law of 1998 substituted the law of 1956, the Wet Economische Mededinging, which allowed cartel agreements as long as they were reported to the Ministry of Economic Affairs, following the German tradition.

Also in other European countries, the European competition law now forms the basis of their national competition laws.

The enforcement of competition law can take different forms. Particularly in the first decades, a clear 'per se rules' approach was followed based on simple rules of thumb, leaving little scope for the enforcement authorities to depart from specified thresholds. Lawyers played a central role in the decision making process on competition cases. Both in the US and the EU, however, there is a trend towards a 'rule of reason' approach (Christiansen and Kerber 2006). In Europe, a trend to base competition policy on a 'more economic' approach comes to the fore in the improved economic analysis in the assessment of specific competition cases (for an overview, see Neven 2006). This more economic approach has been justified by new insights from economic literature on the potential (positive as well as negative) welfare effects

1 For a more extensive overview, see Motta (2004). 
of certain business practices. Especially in merger control, increasing attention is given to economic arguments and models. Economic insights also prove important for evaluating proposed remedies. In article 82 on the abuse of dominant positions, the interpretation is still rather formalistic. There is, however, a development towards a more effect-based approach (Neven 2006: 746).

\section{ECONOMIC EFFECTS}

Together with this more economic approach in competition cases, attention for the economic effects of enforcement activities by the competition authorities is also growing. During the past decade, several national competition authorities have proposed methodologies for measuring the economic effects. There are at least three reasons for conducting such studies:

- the external accountability of the competition authority;

- quality control of the decisions; and

- evaluation of the effectiveness of the competition law.

Accountability is particularly requested by politics. For instance in the US, the Government Performance and Result Act of 1993 is one of the reasons why the US Department of Justice (US DoJ) and the Federal Trade Commission (FTC) have been calculating the impact of their enforcement activities ever since 1999 (see Nelson and Sun 2001). Also in the UK, measurement of the impact of enforcement activities is important as consumer savings is one of the targets to be met by the Office of Fair Trading (OFT). Under the 2007 Comprehensive Spending Review settlement, the OFT agreed to the target that the direct financial benefits to consumers are at least five times that of OFT's cost to taxpayers. The Netherlands Competition Authority has been publishing consumer savings in its annual reports since 2004.

Ex post evaluation for quality control focuses on the internal learning processes of the authority. Evaluation studies can help competition authorities detect past errors and understand the reasons which led to those errors. Court rulings also provide a type of ex post evaluation for some decisions of the competition authority.

Finally, the issue of effectiveness refers to the overall design of the competition policy regime and its enforcement. Several benchmarks have been developed to evaluate and compare different competition regimes. For instance, the OECD has carried out several peer reviews for different countries and the Global Competition Review publishes annual ratings of the different competition authorities. 


\subsection{Measurement}

This Special Issue brings together several papers discussing the measurement of the economic effects of competition law enforcement. ${ }^{2}$ A quantitative assessment of these effects can serve a broader purpose than just the evaluation of competition law enforcement. For instance, it may also influence the choice of priorities in fighting anti-competitive practices or establish the size of damages to be paid in compensation for concrete anti-competitive practices. Gunnar Niels and Reinder van Dijk show how the choice of the counterfactual depends on the purpose of the exercise. By and large, the list of costs and benefits to be assessed is fixed, but some categories will prove more important than others in any particular type of exercise. The economic benefits should include productive and allocative efficiency, enhanced dynamic competition and innovation, enhanced market functioning and macro-economic effects. Like other authors in this Special Issue, they note that assessments of economic effects often assume that the decisions of the competition authority have all been correct. However, a proper evaluation should allow for type I and type II errors.

\subsection{Evaluation Criteria}

There appears to be some controversy regarding the proper concept for measuring costs and benefits: consumer welfare or social welfare? Is the net benefit of breaking a monopoly equal to the consumer savings obtained because the competitive price is below the monopoly price, or should we subtract the loss of monopoly profits to the producer, leaving only the Harberger triangle, i.e. the social welfare gain that results from the elimination of the deadweight loss? Some authors claim that economists should promote targeting social welfare. They appear to ignore the more basic issue that any aggregate welfare measure must attach weights to changes in the welfare of different people, which implies a normative (and hence political) position right from the start. On the other hand, Niels and Van Dijk warn against focusing solely on consumer welfare, because they think economic efficiency should come first in assessing competition policy. They propose including all costs and benefits to all the various participants in the calculations, monetising them as far as possible to make them comparable. If considered appropriate, different weights can then be given to different groups. Jarig van Sinderen and Ron Kemp provide a further discussion, recalling the idea that focusing on consumer welfare

2 The papers draw on contributions that were originally prepared for a workshop on Measuring the Economic Effects of Competition Law Enforcement, held in October 2007 at the Netherlands Competition Authority. The editors gratefully acknowledge the support of the Netherlands Competition Authority in producing this Special Issue. 
may be a suitable tactic in maximising social welfare, a point which is also stressed by Pierluigi Sabbatini.

Many authorities have the explicit target to enhance consumer welfare. The EU Directorate-General for Competition states as its mission "to enforce the competition rules of the Community Treaties, in order to ensure that competition in the EU market is not distorted and that markets operate as efficiently as possible, thereby contributing to the welfare of consumers and to the competitiveness of the European economy". ${ }^{3}$ Competitiveness suggests productive efficiency, but surely does not include all monopoly profits.

Van Sinderen and Kemp review studies of the macro-economic effects of competition policy. They argue that, besides the calculation of consumer savings or welfare effects, information on more macro-economic variables such as economic growth, employment and productivity are also important, especially for the political debate on competition and deregulation. Several model calculations and sector studies from the literature suggest positive effects on GDP, employment and in most cases also on productivity. To these studies, they add their own estimates for the Netherlands, obtained with a new method. They use a conventional estimate of consumer savings and show how it can be interpreted as a cut in the "market power wedge", which is comparable to a cut in the tax wedge. This then allows a simulation with a macroeconomic model to assess the macroeconomic effects of increased competition. It shows that GDP, consumption, investments and employment have all grown in response to the enforcement of the Competition Law of 1998.

\subsection{Measuring Welfare Gains Obtained by the Competition Authority}

Several authors note that the estimated direct gains to consumers from antitrust policies alone tend to be well in excess of the budget costs of the Competition Authority enforcing them. Indirect gains, such as those obtained from deterring other cartel behaviour and net gains from merger control will add to the benefits of the Authority. Mats Bergman warns that benefits from cartel enforcement may often be exaggerated relative to those of merger control. Of course, the Authority may also generate losses, in particular from type I errors in abuse of dominant position or merger decisions and the ensuing deterrence of pro-competitive behaviour. Yet, as is also noted by Damien Neven and Hans Zenger, there is little doubt that at aggregate level, Competition Authorities do deliver substantial net welfare gains to consumers.

This leaves open the possibility that the Authority could have done better. The effectiveness of competition enforcement is the main subject of Bergman's paper. He distinguishes between qualitative and quantitative evaluations, where the latter are defined to be only those that include a quantitative 
estimate of consumer savings. Prominent among qualitative evaluations are court appeals, which provide an in-depth evaluation of decisions on individual cases. Peer reviews and customer satisfaction surveys are also useful for assessing whether the Authority is on par with international best practice. Quantitative evaluations clearly serve a purpose in communicating the value of the competition law and the welfare gains obtained from intervention by the Competition Authority. According to Bergman, there is no strong case for a specialised external auditor to assess the authority's performance and the overall impact of its activity. Many of its decisions are already assessed in court and any attempt to measure the aggregate social benefits is likely to be very costly and still bound to fail in accurately estimating the effects of deterrence, arguably the most important effect of competition law enforcement.

Fiammetta Gordon and David Squires discuss the studies that have shed light on the effects of deterrence. Most studies estimate these effects from a survey under selected lawyers. The available evidence confirms that the deterrent effect is more important than the direct effect of a competition authority's work. In a recent study for the UK, the Office of Fair Trading (OFT) estimated consumer savings from deterrence at some $£ 580$ million per year, 3.7 times the direct effects. From the underlying Deloitte survey, Gordon and Squires also draw some suggestions for improving competition policy. They discuss compulsory versus voluntary notification of mergers, procedures for negotiating merger remedies, the type and level of sanctions and the risk of deterring neutral or pro-competitive conduct.

In his critical review of empirical evidence on the effects of antitrust enforcement in the US, Gregory Werden focuses on cartel and merger cases. He explains why an objective assessment based on hard evidence is not possible for deterrence effects or for the effects of enforcement against singlecompetitor exclusionary conduct. For cartels, the available evidence suggests that price effects are substantial - at least $10 \%$ on average. For lack of data, in particular on the counterfactual, the effects of blocking mergers are more difficult to assess and often rely on a calibrated simulation model. In estimating consumer savings from merger control, the US Department of Justice ignores non-price effects and assumes a price elasticity of demand between -1 and -1.5 . Enforcement against horizontal mergers may well produce savings comparable to those of cartel enforcement, although views are divided as to whether those savings could be enhanced by tightening or loosening enforcement standards.

\subsection{Evaluating Decisions of the Competition Authority}

Many empirical studies have focused on assessing the costs and benefits of decisions made in concrete cases by a Competition Authority. The main problems faced in such case studies are the choice of a proper counterfactual and 
the method to estimate the concomitant evolution of economic variables, so that the difference between it and the actual evolution can be considered the economic effects of the decision. In the context of EU merger control decisions, Paolo Buccirossi et al. discuss both the relevant counterfactuals and, for the various cases, the types of empirical techniques that can be used under different circumstances. All four types of techniques (surveys, event studies, structural modelling and non-experimental policy evaluation) have their pros and cons and each has its own special data requirements.

Taking a principal-agent perspective, Damien Neven and Hans Zenger stress that designing an ex post evaluation scheme to assess an agency's success will have an immediate impact on the way the agency operates. In particular when results of the evaluation are used to allocate resources, internally or externally, imprecise measurements of performance may bring about detrimental behavioural responses in an attempt to produce satisfying evaluation results. For example, as long as deterrence effects are not properly taken into account, there is a risk of over-enforcement to the detriment of social welfare. To evaluate the agency's efficiency, average rather than marginal costs and benefits should be used. An efficient agency should reduce its probability of making erroneous decisions only to the extent that the expected gain of reducing it further outweighs the costs. The acceptable level of errors is also affected by the standard of proof laid down by courts and the legal system. Neven and Zenger identify some further pitfalls in competition policy evaluation, including the risk of overlooking merger-specific efficiencies and the methodological limitations of event studies.

Pierluigi Sabbatini offers a fascinating insight into some practical experiences of the Italian Competition Authority. With the benefit of hindsight, he discusses two cases and shows how the behaviour of companies and consumers may hold surprises for the authority. From both cases he draws some lessons for competition authorities. In particular, disclosure of information on anticompetitive behaviour to the general public can make the market more transparent and yield better prospects for entrants. In assessing a merger, the authority should not only study the effects on local relevant markets, but also include possible changes in the incentive structure at a higher level. When divestures are imposed, the appointment of an independent trustee may be required to prevent the depletion of assets.

Open Access This article is distributed under the terms of the Creative Commons Attribution Noncommercial License which permits any noncommercial use, distribution, and reproduction in any medium, provided the original author(s) and source are credited. 


\section{REFERENCES}

Christiansen, A. and W. Kerber (2006), 'Competition Policy with Optimally Differentiated Rules Instead of "per se rules versus rule of reason", Journal of Competition Law and Economics, 2(2), pp. 215-244.

Motta, M. (2004), Competition Policy: Theory and Practice. Cambridge, Cambridge University Press.

Nelson, P. and S. Sun (2001), 'Consumer Savings from Merger Enforcement: A Review of the Antitrust Agencies' Estimates', Antitrust Law Journal, 69, pp. 921-960.

Neven, D.J. (2006), 'Competition Economics and Antitrust in Europe', Economic Policy, October, pp. 741-791. 